\begin{tabular}{|c|c|c|}
\hline BIODIK & $\begin{array}{c}\text { BIODIK: Jurnal IImiah Pendidikan Biologi } \\
\text { ISSN 2580-0922 (online), ISSN 2460-2612 (print) } \\
\text { Volume 7, Nomor 01, Tahun 2021, Hal. 43-52 } \\
\text { Available online at: } \\
\text { https://online-journal.unja.ac.id/biodik }\end{array}$ & BIODIK $(Q)$ \\
\hline
\end{tabular}

Research Article

open Access

\title{
Peningkatan Hasil Belajar Biologi Melalui Model Pembelajaran Rotating Trio Exchange (RTE) Pada Siswa Kelas XI SMA Negeri 23 Maluku Tengah
}

\section{(Improving Biology Learning Outcomes Through the Rotating Trio Exchange Learning Model for Class XI Students of SMA Negeri 23 Maluku Tengah)}

\author{
Wa Ode Sarwita*, Kevin Tamaela, Pricilia Sopratu, Kalsum Selehulano \\ Program Studi Pendidikan Biologi, STKIP Gotong Royong Masohi \\ JIn. Trans Seram, Kota Masohi Kabupaten Maluku Tengah-Indonesia \\ ${ }^{*}$ Corresponding Authors: inthanande75778@gmail.com
}

\begin{tabular}{|c|c|}
\hline Informasi Artikel & ABSTRACT \\
\hline $\begin{array}{l}\text { Submit: } 20-12-2020 \\
\text { Diterima: } 28-02-2021 \\
\text { Dipublikasikan: } 14-03-2021\end{array}$ & $\begin{array}{l}\text { The purpose of this study was to improve the learning outcomes of biology through } \\
\text { the rotating trio exchange learning model for class XI students of SMA Negeri } 23 \\
\text { Maluku Tengah. This research was conducted in the 2020/2021 school year. This } \\
\text { type of research is classroom action research. As a subject, students of class XI } \\
\text { totaled } 24 \text { students. The research was carried out in } 2 \text { cycles and each cycle } \\
\text { consisted of } 4 \text { stages, namely; planning, implementing, observing, and reflecting. The } \\
\text { results obtained indicate that the application of the rotating trio exchange model } \\
\text { carried out is evident from the completeness of the learning outcomes of the first } \\
\text { cycle students by } 25 \% \text { and at the end of the second cycle has increased to } 100 \% \text {. } \\
\text { The score of the observation of student learning activities in cycle I was } 54.17 \% \text {, and } \\
\text { at the end of the second cycle it increased to } 95.83 \% \text {, which means that it was } \\
\text { categorized as very good. Based on the research results obtained, it can be } \\
\text { concluded that improving student learning outcomes can be improved by applying the } \\
\text { rotating trio exchange model. } \\
\text { Keywords: Rotating Trio Exchange Learning Model (RTE), Learning Outcomes }\end{array}$ \\
\hline Penerbit & ABSTRAK \\
\hline $\begin{array}{l}\text { Program Studi Pendidikan } \\
\text { Biologi, Fakultas Keguruan dan } \\
\text { Ilmu Pendidikan, Universitas } \\
\text { Jambi }\end{array}$ & $\begin{array}{l}\text { Tujuan penelitian ini untuk meningkatkan hasil belajar biologi melalui model } \\
\text { pembelajaran rotating trio exchange pada siswa kelas XI SMA Negeri } 23 \text { Maluku } \\
\text { Tengah. Penelitian ini dilakukan tahun ajaran } 2020 / 2021 \text {. Jenis penelitian yang } \\
\text { digunakan adalah penelitian tindakan kelas. Sebagai subjek siswa kelas XI berjumlah } \\
24 \text { siswa. Penelitian telah dilaksanakan dalam } 2 \text { siklus dan masing-masing siklus } \\
\text { terdiri dari } 4 \text { tahapan yaitu; perencanaan, pelaksanaan, observasi, dan refleksi. Hasil } \\
\text { yang diperoleh menunjukkan bahwa penerapan model rotating trio exchange yang } \\
\text { dilakukan terbukti dari ketuntasan hasil belajar siswa siklus I sebesar } 25 \% \text { dan pada } \\
\text { akhir siklus ke-II mengalami peningkatan menjadi } 100 \% \text {. Adapun skor observasi } \\
\text { aktivitas belajar siswa siklus I sebesar } 54.17 \% \text {, dan pada akhir siklus ke-II mengalami } \\
\text { peningkatan menjadi } 95.83 \% \text {, yang artinya berkategori sangat baik. Berdasarkan } \\
\text { hasil penelitian yang diperoleh maka dapat disimpulkan bahwa meningkatkan hasil } \\
\text { belajar siswa dapat ditingkatkan dengan penerapan model rotating trio exchange. } \\
\text { Katakunci: Model Rotating Trio Exchange (RTE), Hasil Belajar. }\end{array}$ \\
\hline
\end{tabular}

This BIODIK : Jurnal IImiah Pendidikan Biologi is licensed under a CC BY-NC-SA (Creative Commons Attribution-ShareAlike 4.0 International License) 


\section{PENDAHULUAN}

Pendidikan merupakan usaha sadar yang dilakukan untuk mendidik dan mengajar siswa, sehingga siswa dapat berkembang dari yang tidak tau menjadi tau. Pembelajaran dikatakan berhasil jika tujuan dari proses pembelajaran yang dilaksanakan dapat tercapai. Oleh karena itu diperlukan suatu proses yang memberikan kesempatan kepada siswa berinteraksi aktif, menemukan suatu pengetahuan dan dapat memecahkan sebuah masalah dalam pembelajaran.

Berdasarkan hasil observasi dan wawancara dengan guru mata pelajaran biologi kelas XI SMA Negeri 23 Maluku Tengah, diperoleh keterangan dari guru terkait pembelajaran yang sudah dilaksanakan, guru belum pernah menerapkan model pembelajaran rotating trio exchange. Menurut guru bahwa yang selama ini terus berlangsung adalah pembelajaran yang masih terpusat pada guru. Akibatnya, siswa cenderung kurang aktif dalam proses pembelajaran dan kurang berkembang. Hal ini dapat memberikan pada hasil proses belajar siswa yang rendah dengan rata-rata nilai biologi 60 sedangkan KKM adalah 70 pada materi sel semester ganjil tahun ajaran 2019/2020. Upaya dalam memfasilitasi keakftifan siswa dalam proses belajar mengajar tentunya harus memperhatikan suasana dan model pembelajaran yang menyenangkan. Membangun interaksi belajar siswa yang aktif baik secara emosional maupun sosial menjadi modal guru. Oleh karena itu, guru tentu harus menyadari bahwa cara mengajar metode konvensional tidak efektif dan efisien untuk meningkatkan hasil belajar siswa.

Salah satu model pembelajaran yang dapat membangkitkan interaksi dalam proses pembelajaran adalah rotating trio exchange. (Silberman, 2018; Sadikin, 2017) menyatakan bahwa model pembelajaran rotating trio exchange dapat digunakan untuk melibatkan siswa secara aktif karena model pembelajaran ini dapat menumbuhkan dan memaksimalkan interaksi antara satu dengan teman lainnya. (Yuliyati, 2016) juga menyatakan bahwa model pembelajaran rotating trio exchange membantu meningkatkan hasil belajar peserta didik dan menumbuhkan keaktifkan peserta didik. Hal ini juga didukung (Amaliah, 2017) menyatakan bahwa penggunaan model rotating trio exchange lebih efektif untuk meningkatkan hasil belajar siswa daripada pembelajaran konvensional.

Kelebihan model rotating trio exchange yaitu struktur yang jelas yang dapat memungkinkan siswa untuk berbagi dengan pasangan dalam kelompoknya dengan waktu yang teratur, siswa mempunyai banyak kesempatan untuk mengolah informasi yang diperoleh, tidak terdapat kebosanan pada saat proses pembelajaran karena siswa akan dirotasi (Dipayana, 2014).

(Silberman, 2018) mengungkapkan bahwa pelaksanaan model pembelajaran rotating trio exchange yaitu siswa dibagi dalam kelompok yang beranggotakan tiga orang; setiap kelompok diberi pertanyaan untuk didiskusikan; setiap masing-masing anggota di dalam kelompok diberi angka 0,1,dan 2; siswa yang bernomor 2 dirotasikan ke kelompok trio dua searah jarum jam sedangkan siswa yang bernomor 0 tetap berada pada posisinya sebagai anggota tetap dari kelompok trio mereka; rotasi trio dalam setiap kelompok disesuaikan dengan pertanyaan yang disediakan.

Dengan demikian bahwa proses pembelajaran bukan sekadar menghafal konsep, tetapi juga dibutuhkan suatu pemahaman, kerjasama serta kemampuan menyelesaikan persoalan pembelajaran. Berdasarkan permasalahan yang telah diungkapkan maka tujuan dari penelitian ini adalah meningkatkan hasil belajar biologi melalui model pembelajaran rotating trio exchange pada siswa kelas XI SMA N 23 Maluku Tengah 


\section{METODE PENELITIAN}

Metode penelitian yang diterapkan adalah penelitian tindakan kelas (PTK) atau classroom action research. (Kunandar, 2016) mengemukakan bahwa penelitian tindakan Kelas merupakan proses pembelajaran berupa sebuah tindakan yang terjadi di dalam kelas yang bertujuan untuk memperbaiki dan meningkatan kualitas pelaksanaan pembelajaran dan hasil belajar. Penelitian ini dilaksanakan pada semester genap, tahun ajaran 2020/2021 di SMA Negeri 23 Maluku Tengah, Kabupatan Maluku Tengah, Maluku. Subjek penelitian adalah siswa kelas XI yang berjumlah 24 siswa, terdiri dari 9 siswa laki-laki dan 15 siswa perempuan.

Desain penelitian mengadaptasi model yang dikembangkan oleh Kurt Lewin. Model ini terdiri dari empat tahapan yaitu: perencanaan (planning), pelaksanaan (acting), pengamatan (observing), refleksi (reflecting) (Kunandar, 2016). Penelitian ini dilaksanakan dalam 2 siklus kegiatan.

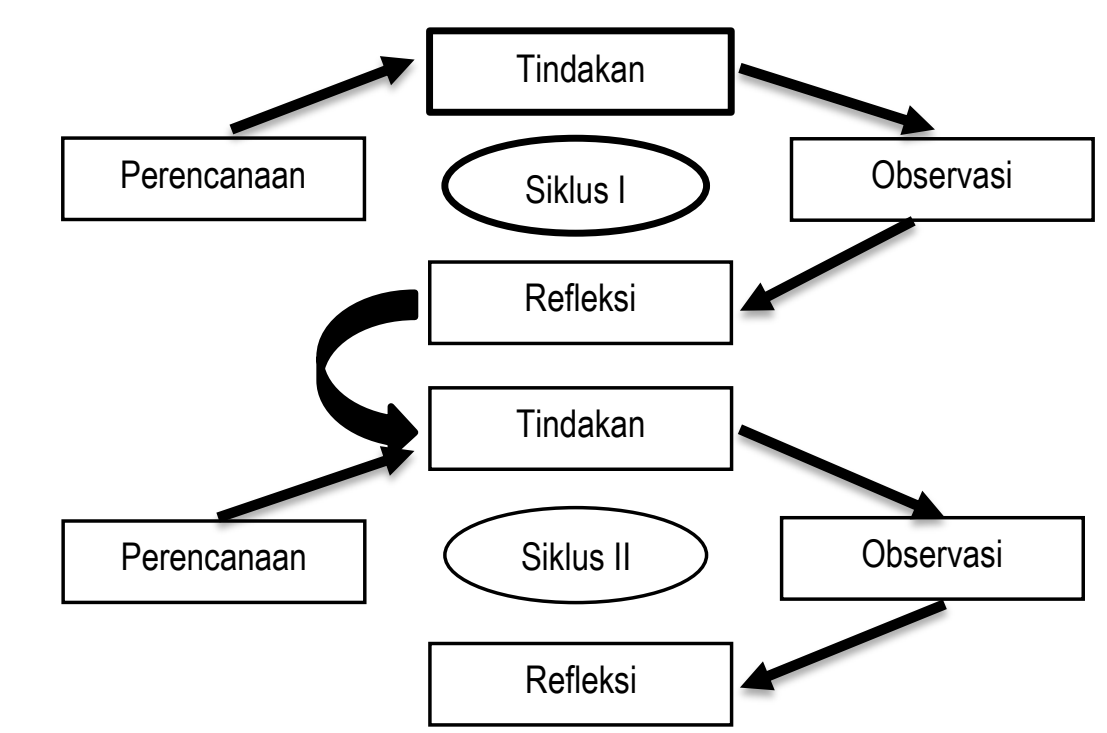

Gambar 1. Bagan Alur Pelaksanaan Penelitian Tindakan Kelas Dengan Model Kurt Lewin

Tahapan pembelajaran:

\section{Planning}

Tahapan yang dilakukan adalah membuat skenario pembelajaran dengan menerapkan model pembelajaran rotating trio exchange, mempersiapkan media yang diperlukan dalam proses belajar mengajar, menyusun lembar observasi untuk menilai aktivitas pembelajaran yang berlangsung, menyusun soal tes.

\section{Acting}

Tahap yang dilakukan guru dan siswa yaitu melaksanakan proses belajar mengajar sesuai dengan skenario pembelajaran. Yang dilakukan pada tahap ini meliputi: memberikan motivasi kepada siswa tentang pentingnya penguasaan materi pembelajaran untuk menunjang materi lain, mengarahkan siswa ke materi pelajaran yang akan dipelajari, melaksanakan tahapan-tahapan pembelajaran sesuai dengan rencana pelaksanaan pembelajaran. Secara umum tahapan pembelajaran pada tiap siklus dilakukan dengan langkah-langkah pembelajaran rotating trio exchange.

\section{Observing}

Tahap ini dilakukan secara berkesinambungan setiap kali berlangsungnya pelaksanaan tindakan. Tahap ini meluputi: pengamatan aktivitas siswa dan guru serta mencatat semua temuan. Hasil temuan 
yang diperoleh digunakan untuk memperbaiki pelaksanaan tindakan-tindakan pada siklus berikutnya, mengevaluasi pencapaian hasil belajar dengan memberikan tes pada setiap akhir siklus.

\section{Reflecting}

Tahap yang dilakukan adalah: peneliti dan anggota tim menganalisa hasil evaluasi, mencari alternative dari temuan-temuan sebagai bahan masukan dalam perencanaan tindakan pada siklus berikutnya (hasil refleksi pada siklus pertama menentukan tindakan pada siklus berikutnya).

Instrumen yang digunakan adalah lembar observasi siswa dan guru dalam pelaksanaan pembelajaran, tes hasil belajar. Tes digunakan untuk mengetahui peningkatan ketuntasan belajar kognitif siswa pada materi sel sedangkan lembar observasi digunakan untuk memperoleh data mengenai aktivitas siswa dan kemampuan guru. Hasil data yang diperoleh kemudian dianalisis secara kualitatif yang disajikan secara deskriptif.

Aktivitas siswa dianalisis dengan menghitung presentase aktivitas siswa yang mencapai kategori aktivitas sangat aktif, aktif, cukup aktif, dan kurang aktif. Persentase aktivitas siswa yang diperoleh dianalisis menggunakan rumus:

$$
\mathrm{P}=\frac{\sum \text { Skor perolehan }}{\sum \text { skor total }} \times 100 \%
$$

Tabel 1. Kategori perolehan nilai aktivitas siswa

\begin{tabular}{ccc}
\hline No & Rentang Nilai & Kategori \\
\hline 1 & $\geq 85$ & Sangat aktif \\
2 & $60-84$ & aktif \\
3 & $35-59$ & Cukup aktif \\
4 & $\leq 34$ & Kurang aktif \\
\hline
\end{tabular}

Sumber: Adaptasi Aqib, 2009

Aktivitas guru dianalisis dengan menghitung presentase kinerja guru dalam pembelajaran yang mencapai kategori aktivitas sangat baik, aktif, cukup baik, kurang aktif, dan sangat kurang. Persentase aktivitas guru yang diperoleh dianalisis menggunakan rumus:

$$
\mathrm{P}=\frac{\sum \text { Skor perolehan }}{\sum \text { skor total }} \times 100 \%
$$

Tabel 2. Kategori keberhasilan kinerja guru

\begin{tabular}{cccc}
\hline No & Skor & Rentang Nilai & Kategori \\
\hline 1 & 5 & $86-100$ & Sangat baik \\
2 & 4 & $76-85$ & Baik \\
3 & 3 & $60-75$ & Cukup Baik \\
4 & 2 & $55-59$ & Kurang Baik \\
5 & 1 & $\leq 54$ & Sangat Kurang \\
\hline
\end{tabular}

Hasil belajar siswa individual dianalisis dengan menghitung ketuntasan belajar yang mencapai kategori tuntas dan tidak tuntas. Data yang diperoleh dianalisis menggunakan rumus yaitu:

$$
\mathrm{P}=\frac{\text { Skor yang diperoleh siswa }}{\text { Skor maksimal }} \times 100 \%
$$


Ketuntasan belajar klasikal dianalisis dengan rumus:

$$
\mathrm{P}=\frac{\text { Banyak siswa yang tuntas }}{\text { Banyak siswa seluruhnya }} \times 100 \%
$$

Untuk mengukur indikator keberhasilan penelitian, maka suatu kelas dikatakan tuntas dalam proses pembelajaran secara klasikal jika persentasi yang dicapai sekurang-kurangnya $75 \%$.

\section{HASIL PENELITIAN DAN PEMBAHASAN}

Hasil yang diperoleh dari proses pembelajaran yang dilakukan dengan menerapkan model rotating trio exchange melalui dua siklus. Data yang diperoleh dalam setiap siklus penelitian ini adalah hasil belajar kognitif siswa, aktivitas siswa dan guru.

\section{SIKLUS I}

\section{a. Planning}

Perencanaan pada siklus pertama dilaksanakan sebagai salah satu upaya untuk memperbaiki dan memecahkan setiap permasalahan yang dihadapi siswa kelas XI SMA Negeri 23 Maluku Tengah. Proses tahapan penelitian ini, peneliti dan guru menyusun perangkat pembelajaran berupa RPP, lembar kerja siswa (LKS), lembar observasi guru dan siswa dan soal tes dalam siklus pertama. Kriteria penilaian yang digunakan dalam pelaksanaan tindakan siklus pertama mengacu pada ketercapaian hasil belajar jika siswa mampu mencapai $>75 \%$.

\section{b. Acting}

Pelaksanaan pembelajaran dengan menerapkan model rotating trio exchange sesuai dengan rencana yang dibuat pada tahap planning. Siklus pertama terdiri dari dua pertemuan dan materi yang diajarkan adalah komponen kimiawi penyusun sel, struktur, fungsi, proses yang berlangsung dalam sel sebagai unit terkecil kehidupan, dan ilmuan yang mengemukakan teori tentang sel, serta kisaran ukuran sel. Pertemuan siklus pertama diakhiri dengan dilakukan tes akhir.

\section{c. Observing Aktivitas Siswa}

Tahap observasi, peneliti melaksanakan proses pengamatan dan pencatatan pada perkembangan yang terjadi dalam kegiatan proses belajar mengajar melalui model rotating trio exchange. Tahap observasi berjalan beriringan dengan dilaksanakannya proses tindakan dalam proses pembelajaran berlangsung. Hal ini peneliti akan mengamati proses berjalannya kegiatan pembelajaran yang dilaksanakan guru dan siswa, kemudian peneliti mengisi lembar observasi yang telah dirancang pada tahap perencanaan.

Tabel 3. Hasil penilaian aktivitas siswa

\begin{tabular}{cccc}
\hline Interval Skor & Frekuensi & Presentase (\%) & Ket \\
\hline $85 \%-100 \%$ & 3 & $12.5 \%$ & sangat aktif \\
$60 \%-84 \%$ & 14 & $58.33 \%$ & aktif \\
$35 \%-59 \%$ & 7 & $29.17 \%$ & cukup aktif \\
$0 \%-34 \%$ & 0 & $0 \%$ & kurang aktif \\
Jumlah & $\mathbf{2 4}$ & 100 & \\
\hline
\end{tabular}


Berdasarkan tabel 1. di atas terlihat bahwa ada 3 siswa (12.5\%) mendapatkan skor nilai 85\%$100 \%$ atau sangat aktif, 14 siswa (58.33\%) mendapatkan skor nilai $60 \%-84 \%$ atau nilai aktif, 7 siswa (29.17\%) mendapatkan skor nilai $35 \%-59 \%$ atau nilai kurang aktif, dan tidak ada siswa yang mendapatkan skor nilai 0\%-34\% atau nilai kurang aktif. Maka persentase keaktifkan siswa pada siklus pertama sebesar $54.17 \%$ yang merupakan kategori cukup aktif.

\section{Aktivitas Guru}

Data penilaian aktivitas guru pada siklus pertama diperoleh melalui lembar observasi selama proses pembelajaran. Adapun hal-hal yang diamati diantaranya: menyampaikan tujuan dan memotivasi siswa, menyajikan atau menyampaikan informasi, mengorganisasikan siswa ke dalam kelompok belajar, membimbing kelompok bekerja dan belajar, evaluasi dan memberikan penghargaan kepada kelompok yang terbaik. Dari hasil lembaran observasi aktivitas guru dalam kegiatan belajar mengajar pada siklus kedua tergolong cukup baik dengan perolehan skor 32 atau $72.72 \%$ sedangkan skor idelnya 44. Hal ini terjadi karena guru lebih banyak berdiri di depan kelas, sehingga pengelolan kelas kurang maksimal; kurang memberikan bimbingan kepada siswa bagaimana melakukan pembelajaran dengan model rotating trio exchange selama diskusi kelompok; guru belum menguasai langkah model pembelajaran dengan baik.

\section{Hasil Belajar}

Disamping melakukan observasi terhadap siswa, peneliti juga melakukan analisis hasil belajar siklus pertama sebagai berikut:

Tabel 4. Hasil Tes Pada Siklus I

\begin{tabular}{ll}
\hline Pencapaian & Nilai \\
\hline Nilai tertinggi & 90 \\
Nilai terendah & 10 \\
Rata-rata nilai tes & 59.17 \\
Tuntas & 6 \\
Tidak tuntas & 18 \\
Presentase ketuntasan & $25 \%$ \\
belajar & \\
Kategori & Kurang baik \\
\hline
\end{tabular}

Berdasarkan tabel 4. diatas dapat dijelaskan bahwa hasil belajar peserta didik pada siklus pertama dapat diketahui nilai rata-rata siswa sebesar 59.17. Nilai tertinggi siswa yang didapatkan sebesar 90 sedangkan nilai terendah siswa sebesar 10. Skor perolehan yang tuntas sebanyak 6 siswa dan yang tidak tuntas sebanyak 18 siswa. Presentase ketuntasan belajar yaitu 25\% dengan kategori kurang baik. Hasil yang diperoleh pada siklus pertama ini belum memenuhi kriteria yang ditentukan oleh peneliti, karena ketentuan untuk presentase ketuntasan belajarnya yaitu $75 \%$ yang diperoleh melalui model pembelajaran rotating trio exchange, sehingga peneliti melanjutkan penelitian ke siklus dua.

\section{d. Reflecting}

Berdasarkan hasil tindakan proses pembelajaran biologi materi sel melalui penerapan model rotating trio exchange serta hasil evaluasi oleh guru dan observer terhadap kualitas pembelajaran biologi, maka ditemukan temuan-temuan yang diperoleh guna meningkatkan hasil belajar. Dari kegiatan refleksi ini diperoleh beberapa hal yang dicatat sebagai masukan untuk melakukan perbaikan tindakan 
selanjutnya, diantaranya: Guru belum terbiasa menciptakan suasana pembelajaran dan pengelolaan kelas yang mengarah pada model pembelajaran rotating trio exchange; perlu bimbingan guru yang merata pada tiap-tiap kelompok; dan sebagian siswa belum terbiasa dengan kondisi belajar menggunakan model pembelajaran rotating trio exchange. Maka pelaksanaan siklus dua dapat dibuat perencanaan sebagai berikut: memberikan motivasi kepada kelompok agar lebih aktif dalam pembelajaran, memberikan bimbingan secara intensif kepada kelompok yang mengalami kesulitan, memberikan penghargaan (reward).

\section{SIKLUS II}

Pada tahap ini, peneliti melakukan perbaikan-perbaikan terhadap materi dari hasil refleksi dari guru dan observer. Untuk itu dilakukan perbaikan agar hasil yang diharapkan lebih baik. Tindakan pada tahap ini dilakukan dengan perencanaan dan persiapan yang lebih matang dibandingkan dengan siklus pertama. Tindakan tahap ini dilaksanakan sebagai upaya untuk memperbaiki dan meningkatkan serta memecahkan masalah pembelajaran biologi khususnya pada materi sel. Langkah pembelajaran siklus kedua terdiri dari:

\section{a. Planning}

Dengan memperhatikan kelemahan dan kekurangan pada pelaksanaan siklus pertama dibuat perencanaan sebelum pelaksanaan tindakan siklus kedua, yaitu: menyusun RPP dan memperbaiki langkah pembelajaran pada siklus kedua, siklus kedua masih menggunakan lembar observasi yang disusun pada tahap perencanaan sebelumnya. Kriteria penilaian yang digunakan dalam pelaksanaan tindakan siklus kedua mengacu pada ketercapaian hasil belajar jika siswa mampu mencapai $>75 \%$.

\section{b. Acting}

Tahap siklus kedua telah dilakukan dengan sangat baik, yaitu mencakup semua unsur sesuai rencana pembelajaran yang telah disusun pada tahap perencanaan. Proses pembelajaran siklus kedua berlangsung dalam dua pertemuan. Materi yang dibahas adalah sel eukariotik dan sel prokariotik, sel tumbuhan dan sel hewan, proses yang berlangsung dalam sel secara transfor aktif, transfor pasif dan osmosis. Tes akhir dilakukan pada pertemuan kedua

\section{c. Observing}

\section{Aktivitas Guru}

Data penilaian aktivitas siswa pada siklus kedua diperoleh melalui lembar observasi selama proses pembelajaran. Adapun hal-hal yang diamati diantaranya: minat belajar, perhatian, partisipasi, persentasi. Dari hasil lembar observasi yang dilakukan, dapat dilihat pada tabel 5.

Tabel 5. Hasil Penilaian Aktivitas Siswa

\begin{tabular}{|c|c|c|c|}
\hline Interval Skor & Frekuensi & Presentase (\%) & Ket \\
\hline $85 \%-100 \%$ & 18 & $75 \%$ & sangat aktif \\
\hline $60 \%-84 \%$ & 6 & $25 \%$ & aktif \\
\hline $35 \%-59 \%$ & 0 & $0 \%$ & cukup aktif \\
\hline $0 \%-34 \%$ & 0 & $0 \%$ & kurang aktif \\
\hline Jumlah & 24 & 100 & \\
\hline
\end{tabular}

Berdasarkan tabel 5. di atas dapat dijelaskan bahwa ada 18 siswa (75\%) mendapatkan skor nilai 85\%$100 \%$ atau nilai $A$ (sangat aktif), 6 siswa (25\%) mendapatkan skor nilai $60 \%-84 \%$ atau nilai B (aktif), tidak ada siswa yang mendapatkan skor nilai 35\%-59\% atau nilai C (kurang aktif) dan tidak ada siswa yang mendapatkan skor nilai $0 \%-34 \%$ atau nilai $D$ (kurang aktif). Maka persentase keaktifkan peserta didik pada siklus kedua sebesar $95.83 \%$ kategori sangat aktif. Semua itu karena peserta didik senang mengikuti pembelajaran 
menggunakan model rotating trio exchange. Siswa sangat antusias, lebih aktif bertanya dan saling bekerjasama dalam kelompok.

\section{Aktivitas Guru}

Data penilaian aktivitas guru pada siklus kedua diperoleh melalui lembar observasi selama proses pembelajaran. Adapun hal-hal yang diamati diantaranya: menyampaikan tujuan dan memotivasi siswa, menyajikan atau menyampaikan informasi, mengorganisasikan siswa ke dalam kelompok belajar, membimbing kelompok bekerja dan belajar, evaluasi dan memberikan penghargaan kepada kelompok yang terbaik. Dari hasil lembaran observasi aktivitas guru dalam kegiatan belajar mengajar pada siklus kedua tergolong sangat baik dengan perolehan skor 42 atau $95.45 \%$ sedangkan skor idelnya 44 . Hal ini berarti kemampuan guru sangat baik dalam proses belajar mengajar. Pada siklus kedua ini juga guru memberikan penghargaan kepada siswa yang berhasil memperoleh nilai tertinggi.

\section{Hasil belajar}

Hasil tes akhir yang dilakukan pada siklus kedua ini mengalami peningkatan dari siklus pertama. Nilai akhir siklus kedua ini dapat dilihat pada tabel 6 .

Tabel 6. Hasil Pada Siklus II

\begin{tabular}{cc}
\hline Pencapaian & Nilai \\
\hline Nilai tertinggi & 100 \\
Nilai terendah & 70 \\
Rata-rata nilai tes & 88.75 \\
Tuntas & 24 \\
Tidak tuntas & 0 \\
Presentase ketuntasan & $100 \%$ \\
belajar & \\
Kategori & Sangat baik \\
\hline
\end{tabular}

\section{d. Reflecting}

Berdasarkan hasil tes menunjukkan bahwa siswa menyukai pembelajaran biologi materi sel melalui penerapan model rotating trio exchange. Pembelajaran dengan menerapkan model rotating trio exchange menjadikan siswa lebih berinteraksi dalam proses pembelajaran, sehingga siswa lebih mudah dalam memahami materi pelajaran yang diberikan. Dari hasil tes yang telah dicapai oleh siswa pada siklus kedua, maka proses pembelajaran telah berhasil dan tidak lagi dilanjutkan pada siklus berikutnya.

\section{PEMBAHASAN}

Berdasarkan observasi pada siklus pertama tahap perencanaan, peneliti menyiapkan perangkat pembelajaran yaitu RPP, media, alat dan bahan serta lembar observasi guru dan siswa. Pada tahap pelaksanaan, pembelajaran berlangsung sesuai dengan rencana pelaksanaan pembelajaran yang telah disusun. Pada tahap ini pelaksanaan kegiatan diskusi dan presentasi kurang memuaskan karena langkah-langkah pembelajaran ini masih baru bagi siswa di kelas, sehingga membuat siswa menjadi canggung.

Tahap observasi pelaksanaan siklus pertama menunjukkan bahwa tingkat aktivitas siswa pada siklus pertama belum mencapai indikator penelitian yaitu 54.17\% kategori cukup aktif. Semua ini tidak terlepas dari kekurangan guru dalam proses pembelajaran berlangsung. Kekurangan yang ditemukan adalah guru belum terbiasa menciptakan suasana pembelajaran dan pengelolaan kelas yang mengarah pada model pembelajaran rotating trio exchange; perlu bimbingan guru yang merata pada tiap-tiap 
kelompok; dan sebagian siswa belum terbiasa dengan kondisi belajar menggunakan model pembelajaran rotating trio exchange.

Berdasarkan hasil analisis pelaksanaan siklus pertama diperoleh bahwa selama siklus petama berlangsung masih terdapat ketidakaktifan antara guru dengan siswa dalam proses pembelajaran berlangsung. Hal ini disebabkan karena masih terdapat siswa-siswi yang kurang serius dalam kegiatan belajar mengajar. Selain itu, ditemukannya juga partisipasi siswa dalam proses pembelajaran kurang menggembirakan dan masih terdapat siswa-siswi dalam kelompok yang tidak ikut peran aktif dalam diskusi maupun merumuskan kesimpulan dalam proses pembelajaran atau hasil belajar.

Kelemahan-kelemahan yang terdapat pada siklus pertama akan diperbaiki pada siklus kedua yaitu dengan memberikan motivasi kepada kelompok agar lebih aktif dalam pembelajaran, memberikan bimbingan secara intensif kepada kelompok yang mengalami kesulitan, memberikan penghargaan (reward).

Aktivitas belajar siswa pada siklus kedua mengalami peningkatan dari siklus pertama yaitu 95.83\% kategori sangat aktif. Pada siklus kedua ini indikator-indikator kinerja penelitian sudah tercapai. Hasil aktivitas guru $95.45 \%$ kategori sangat memuaskan. Keberhasilan proses pembelajaran bukan hanya pada kesiapan belajar guru, tetapi juga dipengaruhi oleh sarana dan prasarana serta sumber belajar. Penggunaan sarana dan sumber belajar yang baik memungkinkan siswa dapat menguasi pelajaran dengan baik. Apabila siswa sudah memiliki kesiapan pan belajar yang didukung dengan saran parasarana maka aktivitas siswa dalam pembelajaran akan meningkat, jika aktivitas meningkat maka hasil belajar akan meningkat pula (Rijal \& Bachtiar, 2015). Hal ini sesuai dengan nilai rata-rata hasil belajar yang diperoleh dari siklus pertama yaitu 59.17 ke siklus kedua yaitu 88.75 . Hasil yang baik dalam belajar ini juga didukung oleh tingkat kemampuan guru yang menyebabkan belajar siswa juga ikut meningkat.

Tercapainya ketuntasan belajar pada siklus kedua dikarenakan semakin meningkatnya keaktifan siswa dalam kegiatan diskusi dimana siswa mampu bertukar pendapat satu dengan yang lainnya dalam proses pembelajaran, pemahaman dan penguasaan konsep siswa. Hasil penelitian ini didukung oleh pendapat (Dipayana, 2014) bahwa "Penerapan teknik merotasi pertukaran pendapat kelompok tiga orang/RTE ini, diyakini dapat meningkatkan keaktifan siswa dalam belajar, karena siswa diajak untuk berfikir secara aktif dalam menyelesaikan soal dari guru".

\section{KESIMPULAN}

Berdasarkan hasil dan pembahasan yang dideskripsikan, maka dapat disimpulkan bahwa hasil belajar biologi materi sel dengan menerapkan model pembelajaran rotating trio exchange pada siswa kelas XI SMA N 23 Maluku Tengah dikategorikan sangat baik dengan nilai rata-rata 88.75.

\section{UCAPAN TERIMA KASIH}

Penulis memberikan ucapan terimakasih/pengakuan kepada pihak yang berkontribusi atas keterlaksanaan penelitian ini. Ucapan terimakasih diberikan kepada Kepala Sekolah SMA Negeri 23 Maluku Tengah yang telah membantu dalam pelaksanaan penelitian ini. 


\section{DAFTAR PUSTAKA}

Aqib, Z.( 2009), Penelitian Tindakan Kelas Untuk Guru SD, SLB \& TK' Bandung: YramaWidya.

Amaliah, R. (2017). Hasil Belajar Biologi Materi Sistem Gerak Dengan Menerapkan Model Pembelajaran Kooperatif Tipe Rotating Trio Exchange (Rte) Pada Siswa Kelas XI SMA N 4 Bantimurung. https://journal.uncp.ac.id/index.php/dinamika/article/view/650

Dipayana, I. D. (2014). Pengaruh Strategi Pembelajaran Rotating Trio Exchange (Rte) Terhadap Hasil Belajar MatematikA. 2(1), 10.

Kunandar. (2016). Langkah Mudah Penelitian Tindakan Kelas Sebagai Pengembangan Profesi Guru (10th ed.). PT Raja Grafindo.

Rijal, S., \& Bachtiar, S. (2015). Hubungan antara Sikap, Kemandirian Belajar, dan Gaya Belajar dengan Hasil Kelajar Kognitif Siswa. http://journal.uad.ac.id/index.php/BIOEDUKATIKA/article/view/4149/0

Sadikin, A. (2017). Pengaruh Penerapan Strategi Pembelajaran Rotating Trio Exchange Terhadap Hasil Belajar Mata Kuliah Dasar-Dasar dan Proses Pembelajaran Biologi. BIODIK, 3(2), 73-80. https://doi.org/10.22437/bio.v3i2.5502

Silberman, M. (2018). Active learning 101 startegi pembelajaran (Ke-XIV, Nopember 2018). Nuansa Cendekia.

Yuliyati, Y. (2016). Penerapan Model Pembelajaran Kooperatif Tipe Rotating Trio Exchange (Rte) Untuk Meningkatkan Hasil Belajar Peserta Didik Pada Mata Pelajaran Fisika. 4(2), 4. 